\title{
How Does Leader-Member Exchange Affect Employee Creativity? The Role of Felt Responsibility for Change
}

\section{Yossi Kalista Dwityaputri ${ }^{\mathrm{a}}$ and Debora Eflina Purba ${ }^{\mathrm{b}}$}

${ }^{a}$ Faculty of Psychology, Universitas Indonesia, Depok, Indonesia; ${ }^{b}$ Department of Industrial and Organizational Psychology, Faculty of Psychology, Universitas Indonesia, Depok, Indonesia

*Corresponding author:

Debora Eflina Purba

Department of Industrial and Organizational Psychology

Faculty of Psychology, Universitas Indonesia

Depok, Jawa Barat, Indonesia

Email address: eflina@ui.ac.id 


\title{
How Does Leader-Member Exchange Affect Employee Creativity? The Role of Felt Responsibility for Change
}

\begin{abstract}
Leadership is an important factor influencing employee creativity. Previous studies have investigated the Leader-Member Exchange (LMX) theory in relation to employee creativity and have found it to yield inconsistent results indicating the occurrence of a mediator between the variables. The present study aims to investigate the role of felt responsibility for change in the LMX-creativity relationship with reference to the social exchange theory. Data were collected using the convenience sampling technique from a sample of 239 employees and from 31 supervisors working in the marketing division of varied types of organizations (banking, manufacture, and service facilities) in Indonesia. The data were analyzed using Hayes' PROCESS macro on the SPSS software. The results revealed that felt responsibility for change significantly took the role of a mediator in the LMX-creativity relationship. The outcomes of this study also demonstrated that felt responsibility for change fully mediated the relationship, as the direct effect of LMX on employee creativity became nonsignificant when the mediator was included in the model.
\end{abstract}

Keywords: employee creativity, felt responsibility for change, Leader-Member Exchange

\section{Introduction}

Creativity is defined as an employee's ability to produce original and useful ideas (Amabile, 1988; Zhou \& Geogre, 2001). Employees who evince creative behavior can improve their work performance, organizational effectiveness, and competitiveness and are better able to achieve the results required from them by the company (Amabile, Conti, Lazenby, \& Herron, 1996). Many factors, both internal and external, can increase the creativity of a company's personnel. This study attends to one the most important external factors that has been found to increase employee creativity: the attribute of leadership (Reiter-Palmon \& Illies, 2004; Tierney \& Farmer, 2004). Leadership is the manner in which a company's principals influence their followers, i.e., their employees, to achieve the goals of the enterprise by enabling them to increase their performance levels, including the enhancement of their creativity (Gong, Huang, \& Farg, 2009; Mittal \& Dhar, 2015; Tierney \& Farmer, 2004; Xu, Zhao, Li, \& Lin, 2017).

The present study focuses on the Leader-Member Exchange (LMX) as a predictor of employee creativity, because LMX centers on the quality of the relationship between the employees and the persons in charge. LMX is defined as the perception of the quality of the affinity between leaders and their subordinates (Dansereau, Graen, \& Haga, 1975). A high-quality relationship is indicated by mutual respect, trust, and the sharing of responsibilities between employees and leaders as evinced by the excellence of their communication and the informal bonding between them. On the other hand, a low-quality association is marked by limited communication between a leader and an employee to the extent described in the job contract (Graen \& Uhl-Bien, 1995). The employee's perception of LMX was given preponderance in the current study because it is 
contended that employees' sense of the quality of the relationship with their leaders actually determines their subsequent attitudes and behaviors within the organization. Employees who perceive high LMX belong to the in-group, and employees who perceive low LMX are relegated to the out-group (Robbins \& Judge, 2016). LMX has been used in organizations as a natural catalyst to encourage employee creativity (Tierney, 2015).

Ample research has been conducted on the relationship between LMX and creativity (Basu \& Green, 1997; Pan, Sun, \& Chow, 2013; Pan, Wu, \& Lou, 2015; Peng, Chen, Xia, \& Ran, 2017; Volmer, Spurk, \& Niessen, 2015; Zhao, Kessel, \& Kratzer, 2013). A literature review of extant studies showed a small correlation coefficient ( $r$ ranging from $=.10$-.30; Pan et al., 2013; Peng et al., 2017; Zhao et al., 2013) on average, indicating that an underlying mechanism occurs between LMX and creativity. Several studies have also found mediators such as self-efficacy, psychological empowerment, felt obligation, and information sharing in the relationship between LMX and creativity (Agarwal, Datta, Blake-Beard, \& Bhargava, 2012; Khazanchi \& Masterson, 2011; Liao, Liu, \& Loi, 2010; Pan et al., 2013). The authors of the current investigation hypothesize that felt responsibility for change may mediate the relationship between LMX and creativity. The responsibility for change is defined as a psychological state in which employees feel personally responsible for incremental improvement beyond the implementation of basic responsibilities in accordance with established standards and are thus driven to institute continuous changes in a performance-oriented workplace (Morrison \& Phelps, 1999). Felt responsibility for change manifests as intrinsic motivation to increase employee creativity and to generate new ideas in the form of work procedures (Jiang \& Gu, 2015).

Previous studies found that felt responsibility for change positively mediated the relationship between proactivity and employee creativity (Jiang \& Gu, 2015). Employees with proactive personalities who are able to feel the urge to act in ways such as pursuing new opportunities or overcoming situations feel that they are responsible for change, and are thus motivated to be creative. Previous studies have also discovered the mediating effect of felt obligation in the relationship between LMX and employee creativity (Pan et al., 2015). Employees who perceive a high-quality relationship with their leader(s) feel obligated to reciprocate by displaying creative behaviors. It may be argued that felt responsibility for change and felt obligation are two different constructs and that by definition, felt obligation is an aspect of felt responsibility for change. Felt responsibility for change may be described as an individual's perception of being duty-bound to effect constructive changes at work and indicates an obligation that goes beyond the prescriptive behaviors outlined in the employee's job description (Morrison \& Phelps, 1999) On the other hand, felt obligation may be defined as the belief that one should take the onus of the wellbeing of the organization and that one must help the organization reach its goals by performing one's job as it has been described by the employer (Eisenberger, Armeli, Lynch, \& Rhoades, 2001). Although both definitions appear similar, felt responsibility for change refers to more specific behaviors toward change and the risks related to achieving the goals go beyond the job description, whereas felt obligation is related to the show of behaviors as prescribed in the job description (Choi, 2007; Fuller, Marler, \& Hester, 2006). Therefore, the authors of this study believe that the present investigation contributes to the existing scholarly 
literature on this topic by illustrating a more specific type of obligation, namely the commitment to change, that is found to be related to creativity, which is usually related to behaviors that go beyond the job description.

Social exchange theory has been employed to assist in the explanation of the relationships among the present study's variables. A basic tenet of social exchange theory is "that relationships evolve over time into trusting, loyal, and mutual commitments" (Cropanzano \& Mitchell, 2005, p. 875). Each member in a social exchange relationship feels responsible for reciprocating any benefits that are received. This paper uses the social exchange theory to argue that felt responsibility for change plays an important role as a mediator in the relationship between LMX and creativity. When employees perceive an intimacy with their supervisor, communicate effectively and in informal settings, and are trusted to perform important tasks in comparison to their peers, they tend to reciprocate this association of value by feeling responsible to effect changes in their work. In turn, the sense of responsibility increases their creativity. Thus, the theoretical model offered in this study is: "Felt responsibility for change will mediate the relationship between LMX and employee creativity.

\section{Method}

\section{Sample and Procedure}

Data for this investigation were collected from employees and supervisors working in the marketing division of varied types of organizations (banking, manufacture, and service facilities) in Indonesia. The predictor and criterion data were incorporated from different sources as suggested by Podsakoff, Mackenzie, Lee, \& Podsakoff (2003) to avoid common method bias, a type of distortion that is likely to occur when the data are collected using the same method. The data on predictor and mediator variables were gathered using self-reporting surveys by the participating employees, and criterion data were accumulated through the supervisor rating method. Some specific codes known only to the researchers were developed to relate the questionnaires distributed to the employees and the questionnaires distributed to the supervisors.

Participants were assured that their engagement was anonymous and confidential, and that they could stop their involvement whenever they desired. It was hoped that in so doing, the participation of employees would increase. Around 300 questionnaires were distributed to the employees and their supervisors. However, only 240 employees and 31 supervisor responses were returned to the researchers (response rate $=80 \%$ ). One response was eliminated because the questionnaire could not be related. Thus, 239 employees and 31 supervisors participated in the current investigation. The participants included 143 males (60\%) and 96 females (40\%). The majority of the sample had attained the education level of a bachelor's degree $(73 \%)$. Tenure of majority of the employees ranged from 1 to 3 years.

\section{Measurements}

Available scales from previous research were employed in this study. The back-translation procedure as suggested by Beaton, Bombardier, Guillemin, and Ferraz (2000) was utilized because all original measures were in English. 
Employee Creativity. This factor was calculated through a four-item employee creativity scale developed by Zhou and George (2001). The attribute of employee creativity was collected using the supervisor rating survey. The sample item was: "This employee tries new ideas or methods first" (responses ranged from 1 = strongly disagree to $6=$ strongly agree). The Cronbach's $\alpha$ was.85.

Leader-Member Exchange. The LMX-7 scale was adapted from Graen and Uhl-Bien (1995). The self-report survey was utilized, with responses ranging from $1=$ strongly disagree to $6=$ strongly agree. The sample item for this feature was "How well does your leader understand your job problems and needs?" The Cronbach's $\alpha$ was.81

Felt Responsibility for Change. A five-item scale by Morrison and Phelps (1999) was employed for this measurement. The mediator variables were assembled using the self-report survey. The sample item for this factor was "I feel a personal sense of responsibility to bring about change at work" and responses ranged from $1=$ strongly disagree to $5=$ strongly agree. The Cronbach's $\alpha$ was. 81

Control variables. Past research has demonstrated that the gender, education, and organizational tenure of employees influenced their creativity (Tierney et al., 1999; Volmer et al., 2012; Zhao et al., 2013). Therefore, the effects of gender $(1=$ male, $2=$ female $)$, education $(1=$ high school or under, 2 = associate degree, 3 = bachelor degree, 4 = master degree), and organizational tenure (in years) were controlled for the purposes of this study.

\section{Results and Discussion}

\section{Confirmatory Factor Analysis}

Before testing the hypotheses, a confirmatory factor analysis was conducted using LISREL 8.80 to test the discriminant validity of the study's measures. The model's overall Chi-square $\left(\chi^{2}\right)$, the comparative fit index (CFI), the root means square error of approximation (RMSEA), goodness of fit index (GFI), and standardized root mean square residual (SRMR) were measured to assess model fit (Hu \& Bentler, 1999). A model is considered suitable when the CFI >.90, RMSEA <.08, GFI >.90, and SRMR <.07 (Hu \& Bentler, 1999). Results indicated that the 3 -factor model of LMX, felt responsibility for change, and employee creativity $\left(\chi^{2}=\right.$ 238.46, $d f=101, \mathrm{CFI}=0.92$, RMSEA $=0.076$, GFI $=0.89$, SRMR $=0.064$ ), provided a better fit to the data than the 1-factor model in which all items are allowed to correlate with one latent attribute $\left(\chi^{2}=1016.44, d f=104, \mathrm{CFI}=0.55, \mathrm{RMSEA}=0.192, \mathrm{GFI}=0.65, \mathrm{SRMR}=0.16\right)$. Therefore, the 3 -factor model was employed in the current investigation. 
Table I. Means, Standard Deviations, and the Correlations among Study Variables

\begin{tabular}{lllllllll}
\hline Variable & $\boldsymbol{M}$ & $\boldsymbol{S D}$ & $\mathbf{1}$ & $\mathbf{2}$ & $\mathbf{3}$ & $\mathbf{4}$ & $\mathbf{5}$ & $\mathbf{6}$ \\
\hline 1. Education & 2.64 & 0.78 & 1 & & & & \\
2. Gender & 1.40 & 0.49 & $.155^{\mathrm{b}}$ & 1 & & & \\
3. Tenure & 3.08 & 2.19 & .085 & .007 & 1 & & \\
4. LMX & 3.69 & 0.48 & -.066 & -.024 & .035 & 1 & \\
5. Felt Responsibility & 4.03 & 0.52 & -.076 & .007 & .059 & $.142^{\mathrm{a}}$ & 1 \\
for Change & 4.44 & 0.79 & -.104 & .015 & $-.166^{\mathrm{b}}$ & $.128^{\mathrm{a}}$ & $.143^{\mathrm{a}}$ & 1 \\
6. Creativity & \multicolumn{7}{c}{ Notes: $\mathrm{N}=239,{ }^{\mathrm{a}} \mathrm{p}<.05,{ }^{\mathrm{b}} \mathrm{p}<.01,(1-$ tailed). Education was dummy-coded $(1=$ high school, 2 = college } \\
degree, $3=$ bachelor degree, $4=$ master's degree). Gender was dummy-coded $(1=$ male, $2=$ female). Tenure was \\
\multicolumn{7}{c}{ measured in years. }
\end{tabular}

The correlations, means, and standard deviations obtained are exhibited in Table 1. Employee creativity was found to positively and significantly correlate with felt responsibility for change ( $r=.14, p=.013)$, and to significantly and negatively associate with tenure ( $r=-.17, p=.005)$. These outcomes indicate that employees with longer tenure in a company tend to evince lower creativity. Felt responsibility for change was significantly and positively correlated with LMX $(r=.13, p=.024)$.

\section{Hypothesis Testing}

Table II. The Role of Felt Responsibility for Change as the Mediator in the LMX - Employee Creativity Relationship Using Hayes' Process macro

\begin{tabular}{|c|c|c|c|c|c|}
\hline Effect & $\boldsymbol{\beta}$ & SE & $p$ & $\begin{array}{l}95 \% \\
\text { LLCI }\end{array}$ & $\begin{array}{l}95 \% \\
\text { ULCI }\end{array}$ \\
\hline LMX $\square$ Felt responsibility for change & .153 & .070 & .029 & .016 & .2907 \\
\hline $\begin{array}{l}\text { Felt responsibility for change } \square \text { Employee } \\
\text { creativity }\end{array}$ & .222 & .098 & .024 & .0291 & .4147 \\
\hline $\begin{array}{l}\text { LMX } \square \text { Felt responsibility for change } \square \\
\text { Employee creativity (total effect) }\end{array}$ & .213 & .105 & .044 & 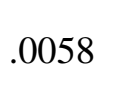 & .4206 \\
\hline LMX $\square$ Employee creativity (direct effect) & .179 & . 105. & .090 & -.0285 & .3868 \\
\hline $\begin{array}{l}\text { LMX } \square \text { Felt responsibility for change } \rightarrow \\
\text { Employee creativity }\end{array}$ & .034 & .023 & - & .0030 & .0996 \\
\hline
\end{tabular}

Notes: $\mathrm{N}=239$. LMX = Leader-Member Exchange, LLCI = Lower Level Confidence Interval; ULCI = Upper Level Confidence Interval, Boostrap sample size $=10000$

The Hayes' PROCESS macro on SPSS software was employed to test the hypothesis which stated that felt responsibility mediated the relationship between LMX and employee creativity. Table 2 demonstrates that the total effect between LMX and employee creativity was significant (total effect $=.213, S E=.105,95 \% C I[.0058,4206$ ), and that the indirect effect of LMX on creativity through felt responsibility for change was also significant (indirect effect $=.034$, BootSE $=.023,95 \%$ CI [.0030,.0996]). These outcomes indicate that felt responsibility for change mediates the relationship between LMX and creativity. The relationship between LMX and creativity became insignificant when felt responsibility for change was included as the mediator (direct effect $=.179, S E=.105,95 \%$ CI [-.0285,.3868]). Hence, it can be concluded that 
felt responsibility for change fully mediates the relationship between LMX and employee creativity. Thus, the data support the researchers' hypothesis.

This study aimed to determine the role of felt responsibility for change as a mediator in the relationship between LMX and employee creativity. The results revealed that felt responsibility for change fully mediated the relation between LMX and creativity. This outcome is aligned with previous research in the sense that felt responsibility for change is a robust mediator for creativity (Jiang \& Gu, 2015) because it represents an employee's internal motivation to perform acts over and beyond the requisite functions to achieve goals or even to exceed the expected targets. The next section will discuss the theoretical and practical implications of the present study.

Previous research has evidenced that the relationship between LMX and creativity is relatively low (Pan et al., 2013; Peng et al., 2017; Wang, 2015; Zhao et al., 2013). In congruence with these previous studies, the current investigation also found a small correlation between LMX and creativity. In addition, responsibility for change was found to be positively correlated with creativity (Duan, Li, Xu, \& Wu, 2016; Fuller et al., 2006; Jiang \& Gu, 2015).

One study reported the mediating effect of felt obligation in the LMX and creativity relationship (Pan et al., 2013). The present study examined felt responsibility for change as the mediator in the LMX-creativity relationship and found that responsibility for change mediated the relationship. In a way, this study confirms the results of Pan et al.'s (2015) study but the authors of this paper contend, as has been discussed above, that felt responsibility for change is different from felt obligation. On the one hand, feeling obligated to reciprocate in exchange for the perceived excellence of one's relationship with one's supervisor drives a person to fulfill the duties as outlined in the job description, and this sense of compulsion may or may not lead to high creativity. On the other hand, feeling responsible for change as a result of the perceived excellence of one's relationship with one's supervisor causes a person to effect constructive changes at work. Therefore, this study contributes to the development of the LMX-creativity theory by advancing a more specific variable, i.e., felt responsibility for change, to the model of creativity. That the creativity variable was rated by supervisors is one of the strengths of the current investigation, as the common method variance is not problematic.

For practical applications, it is suggested that supervisors should ameliorate the quality of their relationships with their subordinates as the supervisor's role is pivotal in instituting and maintaining relationships. Supervisors may enhance the value of their associations with the staff through, for example, the provision of developmental feedback (Jiang \& Gu, 2015). The quality of superior-subordinate associations is characterized by high mutual respect, reciprocal trust, and the feeling of obligation to respond in kind to the other party. This type of connection creates a positive synergy as employees are motivated and feel responsible for displaying their creativity. In addition, managers may attempt to increase their informal communication with all their employees by practicing open office hours, in which the leader intentionally and regularly chooses a period of time to come closer to the subordinates in an open and informal manner (Daft, 2016). 
On the personal level, managers could apply several techniques such as providing the requisite support to their subordinates in the form of verbal encouragement, information, authority, and the construction of safe working environments (Liu, Liao \& Wei, 2015). Supervisors must help employees understand their part in contributing to the overall effectiveness of the organization (Zhang \& Bartol, 2010), and must communicate their high expectations for the creative potential of the employees (Tierney \& Farmer, 2004).

This study acknowledges certain limitations. First, the data used for this investigation was sourced from different organizations in Indonesia, and employee attitudes and behaviors may be influenced by organizational and cultural differences (Farh, Zhong, \& Organ, 2004; Zhao et al., 2013). Although the sample for this study is rather specific, namely marketing employees, organizations with innovative cultures encourage employees to be creative and tolerate errors. On the other hand, organizations with zero tolerance for error may discourage mistakes and thus lower employee creativity. Therefore, the attribute of creativity may vary among organizations. Second, this investigation employed a cross-sectional design that limits its ability to determine the causal relationship between the study variables. Finally, the sample for the study was selected based on the convenience principle which does not allow the generalization of the results.

\section{Conclusion}

The present study found that felt responsibility for change mediated the relationship between LMX and creativity. It contributed to the existing theoretical frameword by incorporating the social exchange theory in the research model, and by testing the model in Indonesia, a relatively under-researched country. Future research should replicate the study in one particular organization which also requires creativity. Forthcoming research should also utilize a longitudinal design to examine the fluctuations in the variables over time, and should plan data collection in a manner that would make the undertaking of a multi-level analysis possible.

\section{References}

Agarwal, U. A., Datta, S., Blake-Beard, S., \& Bhargava, S. (2012). Linking LMX, innovative work behaviour and turnover intentions the mediating role of work engagement. Career Development International, 17(3), 208-230.

Amabile, T. M. (1988). A model of creativity and innovations in organizations. Research in Organizational Behavior, 10(1), 123-167.

Amabile, T. M., Conti, R., Coon, H., Lazenby, J., \& Herron, M. (1996). Assessing the work environment for creativity. Academy of Management Journal, 39(5), 1154-1184.

Aryee, S., Chen, Z. X., Sun, L. Y., \& Debrah, Y. A. (2007). Antecedents and outcomes of abusive supervision: Test of a trickle-down model. Journal of Applied Psychology, 92(1), 191-201.

Basu, R., \& Green, S. G. (1997). Leader-member exchange and transformational leadership: An empirical examination of innovative behaviors in leader-member dyads. Journal of Applied Social Psychology, 27(6), 477-499.

Beaton, D. E, Bombardier, C. Guillemin, F. \& Ferraz, M. B. (2001). Guidelines for the Process of Cross-Cultural Adaptation of Self-Report Measures. SPINE, 25(24), 3186-3191.

Blau, P. M. (1964). Exchange and Power in Social Life. New York: Wiley. 
Brislin, R. W. (1970). Back-translation for cross-cultural research. Journal of Cross-Cultural Psychology, 1(3), 185-216.

Choi, J. N. (2007). Change-oriented organizational citizenship behavior: effects of work environment characteristics and intervening psychological processes. Journal of Organizational Behavior, 28(4), 467484.

Cropanzano, R., \& Mitchell, M. (2005). Social exchange theory: An interdisciplinary review. Journal of Management, 31(6), 874-900.

Daft, R. L. (2016). Organization theory and design (12th ed.). Boston, USA: Cengage Learning.

Dansereau, F., Jr., Graen, G., \& Haga, W. J. (1975). A vertical dyad linkage approach to leadership within formal organizations: A longitudinal investigation of the role-making process. Organizational Behavior and Human Performance, 13(1), 46-78.

Duan, J., Li, C., Xu, Y., \& Wu, C. H. (2017). Transformational leadership and employee voice behavior: A Pygmalion mechanism. Journal of Organizational Behavior, 38(5), 650-670.

Eisenberger, R., Armeli, S., Rexwinkel, B., Lynch, P. D., \& Rhoades, L. (2001). Reciprocation of perceived organizational support. Journal of Applied Psychology, 86(1), 42-51

Farh, J. L., Zhong, C. B., \& Organ, D. W. (2004). Organizational citizenship behavior in the People's Republic of China. Organization Science, 15(2), 241-253.

Forza, C., \& Filippini, R. (1998). TQM impact on quality conformance and customer satisfaction: A causal model. International Journal of Production Economics, 55(1), 1-20.

Frese, M., Fay, D., Hilburger, T., Leng, K., \& Tag, A. (1997). The concept of personal initiative: Operationalization, reliability and validity in two German samples. Journal of Occupational and Organizational Pscyhology, 70(2), 139-161.

Fuller, J. B., Marler, L. E., \& Hester, K. (2006). Promoting felt responsibility for constructive change and proactive behavior: exploring aspects of an elaborated model of work design. Journal of Organizational Behavior, 27(8), 1089-1120.

Gong, Y., Huang, J. C., \& Farh, J. L. (2009). Employee learning orientation, transformational leadership, and employee creativity: the mediating role of employee creative self-efficacy. Academy of Management Journal, 52(4), 765-778.

Graen, G., \& Uhl-Bien, M. (1995). Relationship-based approach to leadership: development of leader-member exchange $(\operatorname{lmx})$ theory of leadership over 25 years: applying a multi-level multi-domain perspective. Leadership Quarterly, 6(2), 219-247.

Hu, L., \& Bentler, P. M. (1999). Cutoff criteria for fit indexes in covariance structure analysis: Conventional criteria versus new alternatives. Structural Equation Modeling: A Multidisciplinary Journal, 6(1), 1-55.

Jiang, W., \& Gu, Q. (2015). A moderated mediation examination of proactive personality on employee creativity. Journal of Organizational Change Management, 28(3), 393-410.

Joo, B.-K. B., \& Ready, K. J. (2012). Career satisfaction: the influences of proactive personality, performance goal orientation, organizational learning culture, and leader-member exchange quality. Career Development International, 17(3), 276-295.

Khazanchi, S., \& Masterson, S. S. (2011). Who and what is fair matters: A multi-foci social exchange model of creativity. Journal of Organizational Behavior, 32(1), 86-106.

Liao, H., Liu, D., \& Loi, R. (2010). Looking at both sides of the social exchange coin: A social cognitive perspective on the joint effects of relationship quality and differentiation on creativity. Academy of Management Journal, 53(5), 1090-1109.

Mittal, S., \& Dhar, R. L. (2015). Transformational leadershipvand employee creativity mediating role of creative self-efficacy andvmoderating role of knowledge sharing. Management Decision, 53(5), 894-910.

Morrison, E. W., \& Phelps, C. C. (1999). Taking charge at work: extra-role efforts to initiate workplace change. Academy of Management Journal, 42(4), 403-419.

Olsson, L., Hemlin, S., \& Pousette, A. (2012). A multi-level analysis of leader-member exchange and creative performance in research groups. The Leadership Quarterly, 23(3), 604-619.

Pan, W., Sun, L. Y., \& Chow, I. H. S. (2013). Leader-Member Exchange and Employee Creativity: Test of a Multilevel Moderated Mediation Model. Human Performance, 25(5), 432-451. 
Pan, J., Wu, Q., Zhou, W., \& Lou, Y. (2015). When is the leader's creativity related to the followers' creativity? Cross-level examination in China. Innovation: Management, Policy \& Practice, 17(3), 365-382.

Parker, S. K., \& Collins, C. G. (2010). Taking stock: Integrating and differentiating multiple proactive behaviors. Journal of Management, 36(3), 633-662.

Peng, J., Chen, Y., Xia, Y., \& Ran, Y. (2017). Workplace loneliness, leader-member exchange and creativity: The cross-level moderating role of leader compassion. Personality and Individual Differences, 104, 510-515.

Podsakoff, P. M., MacKenzie, S. B., Lee, J. Y. \& Podsakoff, N. P. (2003). Common Method Biases in Behavioral Research: A Critical Review of the Literature and Recommended Remedies. Journal of Applied Psychology, 88(5), 879-903.

Reiter-Palmon, R., \& Illies, J. J. (2004). Leadership and creativity: Understanding leadership from a creative problem-solving perspective. The Leadership Quarterly, 15(1), 55-77.

Robbins, S. P., \& Judge, T. A. (2016). Organizational behavior (16th ed.). Boston; Pearson.

Scott, S. G., \& Bruce, R. A. (1994). Determinants of innovative behavior - a path model of individual innovation in the workplace. Academy of Management Journal, 37(3), 580-607.

Tierney, P. (2015). LMX and creativity. In T. N. Bauer \& B. Erdogan (Eds.), The Oxford handbook of leadermember exchange. Oxford, England: Oxford University Press.

Tierney, P., \& Farmer, S. M. (2004). The pygmalion process and employee creativity. Journal of Management, 30(3), 413-432.

Tierney, P., Farmer, S. M., \& Graen, G. B. (1999). An examination of leadership and employee creativity: The relevance of traits and relationships. Personnel Psychology, 52(3), 591-620.

Van Dyane, L., Jehn, K. A., \& Cummings, A. (2002). Differential effect of strain on two forms of work performance: Individual employee sales and creativity. Journal of Organizational Behavior, 23(1), 5776.

Volmer, J., Spurk, D., \& Niessen, C. (2012). Leader-member exchange (LMX), job autonomy, and creative work involvement. The Leadership Quarterly, 23(3), 456-465.

Wang, C. J. (2016). Does leader-member exchange enhance performance in the hospitality industry? The mediating roles of task motivation and creativity. International Journal of Contemporary Hospitality Management, 28(5), 969-987.

Xu, B. D., Zhao, S. K., Li, C. R., \& Lin, L. C. (2017). Authentic leadership and employee creativity: testing the multilevel mediation model. Leadership \& Organization Development Journal, 38(3), 482-498.

Yuan, F. R., \& Woodman, R. W. (2010). Innovative behavior in the workplace: The role of performance and image outcome expectations. Academy of Management Journal, 53(2), 323-342.

Zhang, X. M., \& Bartol, K. M. (2010). Linking empowering leadership and employee creativity: The influence of psychological empowerment, intrinsic motivation, and creative process engagement. Academy of Management Journal, 53(1), 107-128.

Zhao, H., Kessel, M., \& Kratzer, J. (2013). Supervisor-subordinate relationship, differentiation, and employee creativity: A self-categorization perspective. The Journal of Creative Behavior, 48(3), 165-184.

Zhou, J., \& George, J. M. (2001). Awakening employee creativity: The role of leader emotional intelligence. The Leadership Quarterly, 14(4-5), 545-568. 